\title{
Electoral Performance and Policy Choices in the Front National
}

\section{James Shields*}

School of Languages and Social Sciences, Aston University, Birmingham B4 7ET, UK

*Correspondence: j.g.shields@aston.ac.uk

This article proposes a two-level analysis of the Front National (FN) in the 2017 French presidential and parliamentary elections. The first level focuses on the electoral performances of Marine Le Pen and the FN and analyses both elections in terms of gains and losses at the polls. The second level considers FN policy and argues that the party went into these elections with a programme targeting both left-leaning and right-leaning voters, attempting a policy synthesis that partly fitted and partly subverted Kirchheimer's paradigm of the 'catch-all' party. Both levels of analysis link to a number of strategic considerations prompting debate within the party over the direction to take in order to improve its future electoral prospects.

\section{Far-right populism, the Front National and the electoral context of 2017}

The literature on radical right-wing populism has tended to treat the French Front National (FN) as a test case in the making (Camus and Lebourg 2017; Mudde 2017; Akkerman, de Lange and Rooduijn 2016; Benveniste 2016; Judis 2016; Beauzamy 2013; Reynié 2011). As Europe’s premier far-right populist party, the FN has plotted a gradual upward course in both elections and opinion polls since its initial breakthrough in the mid-1980s. While other far-right parties have either perished or been drawn into collusion with mainstream parties (de Lange 2012), the FN has sustained its solitary advance, making a virtue of its outsider status (Perrineau 2014). 
Given a sufficiently favourable political context, could this party reach a 'tipping point' (Eatwell 2005) to move beyond its historic role as a party of opposition and mount a challenge for national power?

Diverse studies of the FN have in turn revisited this question, analysing the distinctive conditions within French politics that might impede or assist such a development (Jaffré 2017; Ehrhard 2015; Perrineau 2015; Mayer 2013, 2015; Delwit 2012; Mergier and Fourquet 2011). In opposition to factors weighing in the FN's favour (economic crisis, high unemployment, disillusion with mainstream politics, an acute security threat), a number of well-established reasons can be adduced to explain the limitations of the party's electoral performances to date: its isolation within the French party system; its inability to grow its vote significantly between the two rounds of elections; the traditional tendency towards a 'Republican front' in run-offs featuring the FN; the limits to public support for FN policies; and low levels of confidence in the party's ability to govern. All of these positive and negative factors played into the presidential and parliamentary elections of 2017, with the balance between them likely to determine whether these elections might precipitate a downturn in the fortunes of Marine Le Pen and the FN or mark a further stage in their continued rise.

The 2017 elections fell at a juncture that lent added urgency to this question of the FN's performance. Within a year of the Brexit referendum in the United Kingdom, the election of Donald Trump in the United States, and the failure of Norbert Hofer and Geert Wilders to carry their parties to power in Austria and the Netherlands, attention was focused on Le Pen and the FN as a gauge of whether the tide of populist insurgency was rising or receding. This article addresses that question through an analysis of Le 
Pen's and the FN's electoral performances in 2017 and assesses the significance of these elections for the FN's place within a changing political landscape and shifting dynamics of electoral competition in France.

\section{The 2017 presidential election: winning, losing and advancing}

The presidential election of 2017 was both a victory and a defeat for Marine Le Pen. The victory, long foretold in opinion polls, was the FN leader's qualification for the run-off. The defeat lay not just in the election of the independent centrist Emmanuel Macron as president, but also in the higher than predicted margin that separated the two. Le Pen went into the second round of this election with polls predicting a score close to $40 \%$. Seen in that light, her actual score of $33.9 \%$ fell some way short of her own and her party’s hopes.

Though the $21.3 \%$ gained in the first round was enough to see Le Pen through, it too concealed elements more akin to defeat than victory. Having led the poll in voting intentions throughout the pre-campaign, Le Pen finished second to Macron’s 24\%. Worse from the FN leader's point of view was the downward momentum that saw her predicted score fall from 28\% as late as mid-March (Opinionway Présitrack 2017; Les Echos.fr 2017), with a loss of 6-7\% over the crucial four weeks preceding the election. In the same period, Macron consolidated his predicted score at around 24\%, François Fillon reversed something of the damage done by corruption allegations to stabilise at 19-20\%, and Jean-Luc Mélenchon staged a remarkable surge from 11-12\% to 1819\%. 
In early March 2017, Le Pen’s predicted first-round score remained broadly in line with the upward trajectory of her party in nationwide elections since 2014 (Kantar Sofres 2017a) - 24.9\% in European elections, 25.2\% in departmental elections and $27.7 \%$ in regional elections. This sequence of unprecedented results had led the FN to claim the mantle of 'first party of France'. In the monthly findings of the French Electoral Survey run by the political research centre at Sciences Po Paris (CEVIPOF), from September 2016 to February 2017 voting intentions for Le Pen varied by just two points (25-27\%) while those for Macron varied by 13 points (10-23\%) and those for Fillon by 8.5 points (27-18.5\%) (Perrineau 2017a).

This relative solidity of Le Pen's electorate was a function of what Pascal Perrineau called its ‘fidélisation’ over both the short and longer terms. From January to February 2017, the FN leader held $91 \%$ of her intended vote compared to Fillon's $75 \%$ and Macron’s 77\%. Going back to the previous presidential election of 2012, Le Pen retained $84 \%$ of her support base while Fillon attracted 55\% of Nicolas Sarkozy's former electorate and Macron 40\% of François Hollande’s. This stability in the Le Pen vote, Perrineau concluded, was explained above all by the progressive structuring of FN support along class-based lines, with the party and its candidate commanding consistently high support among blue-collar workers and those finding it difficult to get by on their income (Perrineau 2017a).

Yet, going into the first round of voting in 2017, Le Pen was the only one of the four main candidates struggling to reverse the downward trend of her polling. Whereas preelection polls had given her on average a 3-4\% lead over Fillon and Mélenchon, her 
margin of victory was narrower $-1.3 \%$ ahead of Fillon (on 20\%) and $1.7 \%$ ahead of Mélenchon (on 19.6\%). And though it set a record for an FN candidate in a presidential election, Le Pen’s first-round score of 21.3\% also raised questions about the party’s momentum over the longer term. Against the $17.9 \%$ won by Marine Le Pen in 2012, it showed a gain of $3.4 \%$ in five years; against the $16.9 \%$ won by her father, JeanMarie Le Pen, in 2002, it showed a gain of $4.4 \%$ over 15 years; and against the $14.4 \%$ won by Jean-Marie Le Pen in 1988, it marked a gain of 6.9\% over 29 years (see Table 1). This was hardly evidence of a dynamic momentum in the FN's capacity to grow its vote share in presidential election first rounds.

Table 1. Le Pen vote in presidential elections 1974-2017

\begin{tabular}{|c|c|c|c|c|}
\hline & & Votes & Vote share (\%) & Electoral register (\%) \\
\hline 1974 & & 190,921 & 0.7 & 0.6 \\
\hline 1988 & & $4,376,742$ & 14.4 & 11.5 \\
\hline 1995 & & $4,571,138$ & 15.0 & 11.4 \\
\hline 2002 & (1 $1^{\text {st }}$ round $)$ & $4,804,772$ & 16.9 & 11.7 \\
\hline & ( $2^{\text {nd }}$ round) & $5,525,034$ & 17.8 & 13.4 \\
\hline 2007 & & $3,834,530$ & 10.4 & 8.6 \\
\hline 2012 & & $6,421,426$ & 17.9 & 13.9 \\
\hline 2017 & (1 $1^{\text {st }}$ round) & $7,678,491$ & 21.3 & 16.1 \\
\hline & (2nd round) & $10,638,475$ & 33.9 & 22.4 \\
\hline
\end{tabular}


Source: Ministère de l'Intérieur (2017a - for 2002-2017) / France Politique (2017a for 1974-1995).

A number of contextual reasons can be invoked to explain Le Pen's lower than predicted vote share in the first round of this election. First, the FN candidate suffered - unusually - from a lack of media focus as allegations of financial impropriety against Fillon and the surge by Macron then by Mélenchon occupied the headlines in turn. She managed only once - with her historically perverse denial of France’s responsibility for the infamous Vél d’Hiv round-up of Jews in Paris in July 1942 - to force herself into the headlines with questionable effect. Second, the judicial cases hanging over Le Pen, notably in relation to alleged misuse of European Parliament funds, deprived her of an uncontested claim to probity and of the freedom both to denounce the political class as corrupt and to capitalise on Fillon's discomfiture. Third, by favouring leftward appeals to economically and socially disadvantaged voters, Le Pen neglected a culturally, socially and economically conservative base largely captured in this election by Fillon. And finally, at 22.2\%, abstention was much lower than the $35 \%$ some polls had anticipated - therefore Le Pen's predictably solid score translated as a lower share of a larger than anticipated turnout.

Despite an apparently conducive wider context framed by the migrant crisis and the terrorist threat (vividly reanimated by a gun attack on police on the Champs-Elysées three days before the first round of voting), Le Pen's campaign struggled not only to increase but to sustain its momentum. Rivalled by Fillon on issues of national identity, immigration and security, by Mélenchon on calls for a clear-out of the political class, 
and by Macron on the claim to represent political renewal, Le Pen had difficulty projecting the distinctiveness of her candidacy (Le Monde 2017a).

Behind a weaker than anticipated performance, however, there were very pronounced strengths. Le Pen increased her 2012 score by over 1.25 million votes. She topped the poll in 8 of France's 13 metropolitan regions, stretching in two concentrated swathes across the north/north-east and south/south-east of the country, with the other five regions giving Macron the lead. Le Pen came first in Bourgogne-Franche-Comté (25\%), Centre-Val de Loire (23\%), Corsica (27.9\%), Grand-Est (27.8\%), Hauts-deFrance (31\%), Normandie (23.9\%), Occitanie (23\%) and Provence-Alpes-Côte d'Azur (28.2\%). What was most striking in the results across these regions was the coherence of the Le Pen vote. The FN leader came top in seven of the eight departments in Bourgogne-Franche-Comté and in five out of six departments in Centre-Val de Loire; she swept all ten departments in the Grand-Est and all five in Hauts-de-France, and she came first in five of the six departments in Provence-Alpes-Côte d'Azur (Le Monde 2017b).

More generally across the 101 departments of France, Le Pen came first in 47 and Macron in 43, with particularly strong Le Pen support in many rural departments but also in more industrialised departments in the north and north-east and along the Mediterranean littoral. The map of support showed the same broad contours of the FN vote as in previous elections going back to the 1980s, with strongest support concentrated east of a diagonal line from the department of Seine-Maritime in the north-west to the Gard department in the south-east. But if the broad outline was familiar, the depth of support and distribution of peaks was quite different. Le Pen's 
score in 2017 exceeded 30\% in 12 of the 47 departments where she came first, with high points of $35.7 \%$ in Aisne and 34.3\% in Pas-de-Calais in the north. In 2012, by contrast, the FN leader had topped the first-round poll in only one department, the Mediterranean Gard, with 25.5\%, and reached her peak with 27\% in the neighbouring Vaucluse (Le Monde 2012).

Analysis of the results across France's 577 parliamentary constituencies showed how accentuated was the strength of the Le Pen vote in the north, confirming the shift away from an FN vote reaching its traditional heights in the south. Le Pen came first in 216 constituencies overall, behind Macron’s lead in 240, while Mélenchon came first in 67 and Fillon in 54 (Libération.fr 2017). Le Pen exceeded 30\% in 83 constituencies, Macron in 52, Mélenchon in 29 and Fillon in 22. The FN leader topped 35\% in 20 constituencies, 18 of those in the northern and north-eastern departments of Pas-deCalais, Nord, Aisne, Oise, Somme, Marne and Haute-Marne, and two in the southern departments of Vaucluse and Bouches-du-Rhône. She reached 40\% and above in three constituencies of Pas-de-Calais and Aisne, including her adopted political base in the former mining town of Hénin-Beaumont in the Pas-de-Calais coalfields (Data.gouv.fr 2017a).

At the most localised level of the commune, Le Pen's results were even more imposing. She topped the first round in 19,038 of France's 35,500 (mostly rural) communes, with Macron coming first in 7,135 and Fillon in 5,753 (Le Parisien.fr 2017). This performance replicated that of her party in the regional elections of December 2015, where it too had come first in some 19,000 communes across France - a fact mostly overlooked in the larger-lens analyses of those elections at the regional 
level (Barbier 2015). What the presidential first round again showed was the growing implantation of the FN and Le Pen vote in more thinly populated and widely spread communes of rural and semi-rural France, compared with more concentrated urban populations where Macron drew his strongest support.

Le Pen's strength, however, was not restricted to rural zones. In some towns across the north, east and south-east, the FN leader posted powerful first-place scores $-41.6 \%$ in Liévin, 37.2\% in Calais, 36.7\% in Lens, 33.9\% in Wattrelos, 31.2\% in Maubeuge, 35.3\% in Saint-Dizier, 32.4\% in Menton, $42.5 \%$ in Marignane, 33.9\% in Orange, 33.8\% in Vitrolles, 33.3\% in Istres, 32.4\% in Draguignan and 30.5\% in Martigues. In towns governed by the FN or with FN support, Le Pen performed especially strongly, coming first with 46.5\% in Hénin-Beaumont, 40.8\% in Beaucaire, 34.3\% in VillersCôtterets, 34\% in Le Pontet, 33.4\% in Cogolin, 31.2\% in Béziers, 33.5\% in Hayange as in Fréjus, and $29.7 \%$ in the $7^{\text {th }}$ sector of Marseille. Le Pen also came first with $30.6 \%$ in Carpentras, where her niece Marion Maréchal-Le Pen had held one of only two FN seats in the National Assembly since 2012 (Le Monde 2017b).

Le Pen attained her highest proportion of the first-round vote among blue-collar workers (39\%), routine non-manual employees (30\%), and those with low or no educational qualifications (31\%) (IFOP 2017). She drew 6\% of Hollande voters and 4\% of Mélenchon voters from 2012, with these one-time left-leaning voters being decisive in securing her margin of victory over Fillon (465,000 votes). Le Pen took the highest share of support across rural communes (26\%) and among voters considering themselves 'losers of globalisation' (34\%). The same polling also found that $76 \%$ of Le Pen voters had decided on their candidate long before the election - a much higher 
figure than that for any other main candidate. The major motivating issues in the Le Pen vote were the fight against terrorism (for 93\%), illegal immigration (92\%) and petty crime (85\%). What was not a strong motivating factor was Le Pen’s presidential stature (recognised by only $15 \%$ of her voters) or the confidence she inspired (recognised by only 9\%).

As measured by the above IFOP poll, the highest proportion of Le Pen's support was among voters aged 35-49, the age group in which Le Pen also polled most strongly in 2012 (IFOP 2012). An Opinionway poll confirmed many of IFOP's findings, placing support for Le Pen at 40\% among blue-collar workers, 30\% among routine non-manual employees and 30\% among unemployed voters, with the highest support again recorded in the 35-49 age group (Opinionway 2017). Polling by IPSOS ascribed a similar socio-economic profile to Le Pen voters, crediting the FN candidate with 43\% of those finding it 'very difficult' to get by on their income, 32\% of those most poorly paid, $14 \%$ of those leaning to the far left, and $21 \%$ of those with no partisan preference (IPSOS 2017a).

Once qualified for the second round, Le Pen found herself confronted with the problem that had always dogged her party in two-way run-offs: how to build on a first-round score sufficiently to achieve an outright majority in the second round. From a base of 21.3\%, that arithmetical challenge seemed insurmountable. Le Pen’s main hope lay in the contradictory imperative of attracting as much of Fillon’s 20\% and of Mélenchon’s $19.6 \%$ of first-round voters as possible - with the additional hope that a high abstention rate might skew the second-round poll in her favour. She gave herself a marginal boost by concluding an agreement with Nicolas Dupont-Aignan, head of the sovereignist 
Debout La France party, who had scored $4.7 \%$ in the first round. More than symbolically significant, this marked the first time in its 45-year history that the FN had concluded a national alliance with any party emanating from the mainstream right.

If this signing of an electoral agreement marked the high point of Le Pen's secondround campaign, the low point came in the head-to-head televised debate four days before the second round. Here she came over as aggressive, ill prepared on policy and no match for Macron's presidentialist credibility - not at all the image of 'Ia France apaisée' ('France at ease with itself') proclaimed by her posters in the first-round campaign. Having gone into the debate at close to $40 \%$ of voting intentions, Le Pen saw her ratings slide (Ipsos 2017b) and went on to attain a run-off score of 33.9\%.

Where Macron added $42 \%$ to his vote share in the run-off, Le Pen added $12.6 \%$. to hers. Having topped the first round in 8 of 13 regions and in more of France's 101 departments than Macron (47 to 43), Le Pen topped the second round in no region and in only two departments: the former left-wing bastions of Pas-de-Calais and Aisne in the north. While crucial vote transfers worked well for Macron, who drew close to half of Mélenchon’s and of Fillon's electorates together with three-quarters of the Socialist Benoît Hamon’s, they functioned poorly for Le Pen, who attracted barely a tenth of Mélenchon's voters and a quarter of Fillon's. And despite the electoral agreement struck with Dupont-Aignan, Le Pen managed to attract around just a third of his limited base (IPSOS 2017c,d).

What looked like a wipe-out at the regional level and a near wipe-out at the departmental level was mitigated by a closer look at the results. Le Pen's score 
exceeded $40 \%$ in 34 departments, rising to over $45 \%$ in 17 of them (Data.gouv.fr 2017b). By contrast, in the second round of the 2002 presidential election, Jean-Marie Le Pen had recorded no departmental score above 30\%, reaching his peaks of support in Vaucluse with 29.6\% and Var with 28.7\% (Data.gouv.fr 2002).

At the level of parliamentary constituencies, the second round like the first highlighted the strength of Le Pen in the north and north-east. She won over $50 \%$ in 45 of the 577 constituencies and $45-50 \%$ in 66 others, reaching over 55\% in 13 constituencies across the northern departments of Aisne, Nord, Pas-de-Calais, Somme and Haute-Marne, and peaking in the $12^{\text {th }}$ constituency of Pas-de-Calais with $60.5 \%$ of the run-off vote (Data.gouv.fr 2017b). Looking ahead to the June parliamentary election, this unprecedented string of results in head-to-head run-offs (normally the sternest test of the FN's electoral capacities) indicated areas where FN strength was deepest and where hopes of winning seats might be most realistically focused. These results also contrasted sharply with Jean-Marie Le Pen's failure to achieve 50\%, or even 40\%, in any constituency in the run-off against Jacques Chirac in 2002, when his highest score was 33.6\% in the $12^{\text {th }}$ constituency of the southern Bouches-du-Rhône (Data.gouv.fr 2002).

At the level of the commune, too, Marine Le Pen's defeat in 2017 was mitigated. She held her first place in 9,194 communes as against Macron’s first place in 26,044 (with 311 splitting evenly) (Baruch 2017) In other ways, too, Le Pen’s second-round score concealed elements of strength. She drew majority support among blue-collar workers (56\%), among those finding it very difficult to get by economically (69\%), and among 
both those classing themselves on the right (53\%) and those refusing to be classed as either left or right (52\%) (IPSOS 2017c).

Strong working-class support was also partly reflected in the urban geography of Le Pen's second-round vote. She came a clear first in working-class towns across the northern region of Hauts-de-France, with $57.4 \%$ in Calais, 53.6\% in Lens, $64 \%$ in Bruay-sur-l'Escaut, 62.9\% in Aniche, 62\% in Vieux-Condé, 64.6\% in Auchel, 60\% in Noeux-les-Mines and 59.2\% in Bully-les-Mines. In other towns, Le Pen consolidated inroads into formerly Communist territory - with 60.2\% in Douchy-les-Mines, 59.5\% in Raismes, 59.4\% in Somain and 58.9\% in Méricourt.

In the Grand-Est, too, some striking scores were recorded (Stiring-Wendel 51.8\%, Wittelsheim 56.4\%, Wittenheim 51.4\%), and in the southern regions of Occitanie and Provence-Alpes-Côte d'Azur a number of towns gave majority support to Le Pen (Agde 54.4\%, Menton 51.2\%, Saint-Laurent-du-Var 52.6\%, Istres 50.5\%, Marignane 60.3\%, Tarascon 55.5\%, Draguignan 50.5\%, Orange 51.8\%). As in the first round, some FN-run towns came out strongly for Le Pen - Beaucaire 55.5\%, Cogolin 51.9\% and Fréjus 50.7\%. In her personal fiefdom of Hénin-Beaumont, Le Pen scored 61.6\% to Macron’s 38.4\% (Le Monde 2017c).

Where the relative strength in Marine Le Pen’s performance (33.9\%, 10.6 million votes) also came through was again in comparison with that of her father in 2002 (17.8\%, 5.5 million votes). Between the two rounds of that election, Jean-Marie Le Pen increased his vote share by just $0.9 \%$, adding some 720,000 votes (compared with Jacques Chirac's 62\% rise adding almost 20 million votes). In raising her vote share 
by $12.6 \%$, Marine Le Pen added almost 3 million votes as against Macron’s increase of 12 million. Given the historic difficulty of the FN in increasing its score between the two rounds of elections, this showed a significant ability to tap into a new reservoir of voters - and this in an election where valid votes between first and second round fell by almost 5 million.

\section{Policy choices and reconciling opposites}

The presidential election of 2017 was the test not just of an FN candidate but also of a political programme. Traditionally, FN manifestos have been devised for presidential contests then developed for the parliamentary elections that have, especially since the aligning of both mandates in 2002, become the normal sequel. Le Pen entered this election with a policy agenda that was close not only to her own platform of 2012 but also to the platforms on which Jean-Marie Le Pen fought the campaigns of 2007 and 2002, when Marine Le Pen first emerged as a significant voice within the FN. The 2017 programme, however, also contained important elements that broke both with more recent party programmes and with the founding policy manifestos of the 1970s and 1980s.

On its privileged themes of immigration, national preference, security and Europe, Le Pen’s programme in 2017 stayed true to key party policies: reduce net immigration annually to a ceiling of 10,000; reserve jobs, social housing and family allowances for French nationals; increase tax on companies employing foreign workers; expel all illegal immigrants and all foreigners convicted of criminal offences; tighten conditions 
for entry, residence and nationality; deny illegal immigrants access to basic healthcare; apply 'zero tolerance’ in judicial sentencing; increase the police force, army, judiciary, intelligence services, prisons and border guards. In the fight against terrorism, Le Pen’s programme proposed to ban all organisations with links to Islamist fundamentalism, close radical mosques, apply 'preventive detention' to those suspected of links with organisations hostile to France, strip nationality from and expel binationals with jihadist links, and expel all foreigners on security watch lists. On Europe, her programme proposed to pull France out of the Schengen Agreement on free movement and restore full border controls; to renegotiate the terms of France's membership of the EU and, as in the first of her 144 Presidential Commitments, recover lost 'monetary, legislative, territorial and economic' sovereignty; and to put the outcome of this renegotiation and the question of France's continued EU membership to a referendum (Le Pen 2017).

There was more to Le Pen’s programme, however, than this familiar litany of favoured proposals. The 2017 programme bore the signs of two marked evolutions in FN discourse and policy. The first of these was the open espousal of the 'values of the Republic'. Le Pen’s 2012 programme had stopped short of this loaded formula on the part of a party that had throughout much of its existence contested the very fundaments of the Republic as a value system and form of government. Though the appropriation of the heritage and symbolism of the Republic had been a conspicuous part of Marine Le Pen's project to 'de-demonise' the FN, the 2017 programme pushed this a stage further by making the Republic the touchstone for the values inculcated in schools, the rule of law and even the assimilation of immigrants within French national identity. A key part of that 'Republican assimilation’ would be ensured through a greater emphasis 
on prohibitive secularism - laïcité - and the extension of bans on conspicuous religious dress and symbols across the public sphere. The 2017 programme went so far as to cite the secularist Jean Zay, Minister of Education under the left-wing Popular Front (193638) and a prime hate figure of the anti-Republican, anti-Semitic right of the inter-war and Vichy years. A glimpse of the reaction in more extreme reaches of the far right to Zay's remains being transferred to the Pantheon in 2015 gives some measure of the singularity of this approving reference in an FN programme (Jeune Nation 2014).

The other marked evolution in Le Pen's platform concerned economic policy. This election brought confirmation of the FN's strategic turn on economic policy towards a left-leaning agenda of state intervention, economic protectionism and social welfarism. Continuing the leftward direction of economic policy since Marine Le Pen assumed leadership of the party in 2011, the 2017 programme pledged an 'Étatstratège' or a state that would intervene to preserve key national industries, protect French companies from global competition, raise welfare spending and ensure the provision of public services in even the most rural locations. There was no echo here of the FN's stridently neo-liberal programme of the 1980s with its calls for phasing out income tax, shrinking the state through privatisations and slashing public spending on the crude maxim: 'less tax and less aid' (Shields 2007: 214). Le Pen's 2017 programme contained a barrage of left-leaning, social-justice-oriented proposals: to abolish the 2016 labour law reforms easing regulations on employers, retain the 35hour work week, offer a cost of living allowance to the lowest earners while cutting their income tax, retain the wealth tax, reduce gas and electricity bills, lower the housing tax, raise the basic state pension, increase disability allowance, hold down 
VAT, exempt overtime from tax, lower retirement age from 62 to 60, and reinvest in public services.

These were policies designed to appeal largely to the FN's growing working-class electorate, but they held less appeal for the traditional base of shopkeepers and small self-employed voters who once formed the FN's core support. This difficulty of reaching out at the same time to blue-collar and lower middle-class voters was a source of some debate within the party during the drafting of the 2017 programme, pitting proponents of a left-oriented strategy around vice-president Florian Philippot against those with more liberal economic instincts around vice-president Louis Aliot, Marion Maréchal-Le Pen and Marine Le Pen’s economic adviser, Jean-Richard Sulzer. It reflected an entrenched divide within the party between an FN in the industrial north that speaks to a socially left-leaning, economically impoverished, protectionistminded electorate and an FN in the south that speaks to a more traditional Catholic, economically liberal and right-leaning base.

This divide between a 'social-sovereignist' and a 'liberal-identitarian' orientation (Courtois 2017) was resolved not by opting for one approach over the other but by trying to combine the two. Hence the inclusion in Le Pen's programme of a raft of proposals to attract right-leaning middle-class voters: reduction in payroll taxes for small and medium-sized businesses, no increase in the minimum wage, preferential borrowing rates for small business, lower corporate tax on small companies, less bureaucracy and improved social security for the self-employed, a reduction in property transfer tax, a clampdown on social security fraud, tighter oversight of trade unions, public procurement rights for French companies and a 3\% tax on imports as a 
cushion against foreign competition. Combined with other proposals targeting more affluent elderly voters, such as less punitive inheritance tax, such appeals to rightleaning voters accounted for a higher proportion of the 2017 programme (over a third) than that of 2012 (just over a fifth) (Ivaldi 2017).

As Gilles Ivaldi (2017) notes, this attempt at a left-right economic synthesis resonated with Otto Kirchheimer's framing of the 'catch-all' party as one where vote maximisation takes precedence over ideological coherence. The more a party seeks to secure an electoral majority, Kirchheimer contended, the more it has to deviate from its ideology and reach beyond its core electorate. If the primary goal is winning the next election, the primary imperative must be to maximise electoral appeal. In Kirchheimer’s paradigm, however, ‘catch-all' parties would necessarily be drawn to the centre of the political space, seeking compromise policy positions and eschewing extremist tendencies as they compete for the median voter; they would not, as in the FN's case, sustain radical positions on the left and seek to combine those, in a synthesis of opposites, with pronounced positions on the right (Kirchheimer 1966; Krouwel 2003; Hale Williams 2009).

\section{The 2017 parliamentary elections: more mixed results}

Held just five weeks after the presidential run-off, the elections to the National Assembly raised the question of whether Macron's presidential victory could be converted into a governing majority for his La République en Marche (LRM) party (Evans and Ivaldi 2017). The associated question for the FN was whether it could 
impose itself as a meaningful force of opposition to Macron's party by improving significantly upon the two National Assembly seats it had won in 2012. Its aim was to win at least the 15 seats required to form a parliamentary group and thereby amplify its voice in the new lower chamber. The party had only once in its history been able to form a parliamentary group, when the switch to proportional representation for the 1986 elections had opened the doors of the National Assembly to 35 FN deputies. In all other elections prior to 2012, the party had won no representation at all or, exceptionally, just a single seat (see Table 2).

Table 2. FN results in elections to National Assembly 1973-2017

$$
\text { Votes (1 } 1^{\text {st }} \text { or single round) } \quad \text { Vote share (\%) Seats }
$$

$\begin{array}{rrrr}1973 * & 122,498 & 0.5 & \\ 1978 & 82,743 & 0.3 & 35 \\ 1981 & 44,414 & 0.2 & 1 \\ 1986 & 2,701,701 & 9.8 & \\ 1988 & 2,353,466 & 9.8 & 1 \\ 1993 & 3,150,764 & 12.7 & \\ 1997 & 3,775,662 & 15.2 & \\ 2002 & 2,873,556 & 11.1 & \\ 2007 & 1,116,136 & 4.3 & 8 \\ 2012 & 3,528,663 & 13.6 & 13.2 \\ 2017 & 2,990,454 & & \end{array}$


* Election in which FN vote was combined with wider extreme-right vote.

Source: Ministère de l'Intérieur (2017b - for 2007-2017) / France Politique (2017b for 1973-2002).

The FN had hoped to go into these elections buoyed by a strong presidential performance from its leader and bidding to seize back the 'first party of France' label it had claimed in the European, departmental and regional elections of 2014-15. Instead, the party struggled to contain its internal dissensions over responsibility for the presidential defeat and over what strategic adjustments, if any, should be made to its programme as a consequence. Vice-president Philippot attracted particular criticism for the left-oriented populist line that had predominated in the Le Pen campaign, his insistence on exiting the euro despite lack of popular support for the policy, and his hardly unifying initiative in launching his own movement, Les Patriotes, at this point. More potentially serious, however, was the FN's inability to re-energise its base for parliamentary elections where only a few seats at most were predicted to come its way.

Fielding candidates in 573 of the 577 constituencies in the first round of the elections on 11 June, the FN won $13.2 \%$ of the vote, the support of just under 3 million voters. This marked a drop from the $13.6 \%$ (3.5 million votes) it had won in 2012; it also marked a drop from the scores recorded by the FN as far back as 1993 (3.15 million votes) and 1997 (3.8 million votes), the latter still standing as its highest ever score in parliamentary elections (15.2\%) (Table 2). More starkly, the 2017 elections showed a loss of $8 \%$ of vote share and of 4.7 million votes against the first round of the 
presidential poll (and a loss of 7.6 million votes against the second presidential round). They also showed a party far short of the rising curve of support recorded in the European, departmental and regional elections of 2014-15, peaking with 6.8 million votes in the second round of the regional elections. By contrast, the FN in 2017 found itself relegated to third place behind Macron's LRM on 28.2\% of the first-round vote and the centre-right Républicains (LR) on 15.8\%.

High points for the FN were first-place finishes for Marine Le Pen in Hénin-Beaumont (46\%), Bruno Bilde in Liévin (35.5\%), Emmanuelle Ménard in Béziers (35.4\%), Sébastien Chenu in Valenciennes-South (33.2\%), outgoing deputy Gilbert Collard in Vauvert (32.3\%), José Evrard in Lens (31.7\%), Ludovic Pajot in Bruay-la-Buissière (31.3\%), Louis Aliot in Perpignan (30.8\%) and Stéphane Ravier in Marseille (30.8\%). In all, FN candidates topped the first round in 20 constituencies compared with only five in 2012. Among the party's national leaders, vice-president Philippot finished first with $23.8 \%$ in Forbach while secretary-general Nicolas Bay failed - just - to make the run-off with 22.8\% in Dieppe (Le Monde 2017d).

FN candidates qualified for the second round in 122 of the 573 constituencies contested, twice as many as the 61 candidates it had seen qualify in 2012 - and a long way from the sole constituency of Hénin-Beaumont in which Marine Le Pen had contested the run-off in the 2007 election. A record high abstention rate of $51.3 \%$ in 2017 raised the qualifying bar for the second round to over $25 \%$ of the vote on average, given the need for candidates to secure $12.5 \%$ of the electoral roll to go through if not finishing in the top two. This cut the number of three-way run-offs (triangulaires) from 34 in 2012 to just one in 2017, increasing the difficulty for FN candidates for whom 
three-way contests present a much more favourable prospect by splitting the anti-FN vote. Those few FN candidates qualifying with a strong lead stood the best chance of translating that to victory in the second round - namely Le Pen (+26 points), Evrard (+15), Bilde (+15), Chenu (+15), Pajot (+11) and Ménard (+11). Though Le Pen had topped the presidential run-off against Macron in 45 parliamentary constituencies, scoring over $55 \%$ in 13 of them, the FN saw its hopes reduced to scraping just a few seats more than its outgoing tally of two.

The second round of voting on 18 June saw the FN win $8.7 \%$ of vote share, the support of 1.6 million voters, in an election that again set a new record for abstention (57.4\%). The FN secured eight seats, the most emphatic victory being that of Le Pen in HéninBeaumont with $58.6 \%$ of the run-off vote against her LRM opponent, Anne Roquet (41.4\%). Wins were also delivered in the Pas-de-Calais by Bilde (55\%), Pajot (52.6\%) and Evrard (52.9\%), in the neighbouring Nord by Chenu (55.3\%), and along the Mediterranean littoral by Aliot (50.6\%), Ménard (53.5\%) and Collard (50.2\%), who held his seat in Vauvert with a margin of just 123 votes (Le Monde 2017e).

Two factors were blamed by Le Pen for her party’s failure to win more seats in these elections: record abstention and an electoral system rigged against the FN. On abstention: 23 million voters turned out in the first round of the parliamentary election as against 37 million in the presidential first round. An IPSOS poll showed the FN to have been the party hardest hit by the low turnout, with 57\% of Le Pen’s voters from April abstaining (IPSOS 2017e). This overturned a traditional pattern whereby the FN, with its highly mobilised support base, had historically been the party best placed to gain from high abstention. The most recent example of this had been the European 
elections in May 2014 where the FN had emerged as the winning party with $24.9 \%$ (4.7 million votes) despite a still higher abstention rate of 57.6\%.

On the electoral system: with $13.2 \%$ of the first-round vote, the FN emerged from the second round with $1.4 \%$ of National Assembly seats. By contrast, Mélenchon's farleft La France Insoumise won 11\% of the first-round vote and 17 seats to the FN's 8. A starker comparison still was with the French Communist Party. With just 2.7\% of the first-round vote, it secured 10 seats, underlining once again the distortive effects of the two-ballot majority voting system and, crucially, the damaging cost of political isolation. The key difference between the FN and much less significant parties (not just Communist but also regionalist and ecologist) lay in their capacity to forge some degree of cooperation with proximate parties. Conversely, that a party whose candidate won a third of the presidential run-off poll should be excluded from meaningful parliamentary representation invites reflection not only on the FN's critical isolation within the party system, but also on the rules governing representative democracy in France.

\section{The FN at a turning point}

The FN's approach to the 2017 presidential and parliamentary elections was informed by a strategy of vote maximisation that left unresolved some contradictions at the heart of its policy agenda. On no issue was this more apparent than on the policy of withdrawing from the EU single currency. This was a policy consistently espoused since the first presidential election following the introduction of the euro in 2002, when 
Jean-Marie Le Pen ran on a platform to 'withdraw France urgently from the Europe of Brussels' and 'oppose the euro as an instrument of France's economic surrender of sovereignty' (Front National 2001: 157-158). This was accompanied by calls for the euro to be converted from a single to a common currency to rival the dollar in international financial markets. In 2012, Marine Le Pen had echoed these same demands, promising a referendum on reverting to the franc as the national currency while retaining the euro as a parallel currency (Le Pen 2012: 2).

By 2017, despite the result of the UK Brexit referendum, it was clear that the proposal to pull France out of the euro did not command popular support (standing at $22 \%$ in the annual poll measuring agreement with the FN's ideas in March 2017, down from 34\% at the start of Marine Le Pen's leadership in 2011) (Kantar Sofres 2017b). As a result, the FN tempered its anti-euro animus in Le Pen’s 2017 presidential programme, promising a period of negotiation with EU partners on restoring 'national sovereignties' followed by a referendum on France's continued membership of the EU (Le Pen 2017: 3).

Whereas the dropping in 2017 of another unpopular policy - restoration of capital punishment - passed without note, the ambiguities of the party's position on the euro were exposed partly in the conditions for the presidential run-off agreement struck with Dupont-Aignan then more damagingly in the televised run-off debate with Macron (Le Monde.fr, 29 April 2017; Ducourtieux, 2017). This shone a harsh light on a policy that had been ill thought through and a presidential candidate who could not articulate a persuasive case in its support. Following the elections, the policy of exiting the euro moved to the centre of an internal debate within the party, pitting its chief 
advocate Philippot against others who saw it as a distraction from the more quintessential issues of immigration, national identity and security (Faye 2017). Philippot resigned from the FN in September 2017, predicting the party's return to the 'old demons' he had worked to cast out through his strategy of 'de-demonisation' (Faye and Soullier 2017).

These differences over the euro are symptomatic of wider existential questions now confronting the FN. Should the party continue cultivating a left-leaning, politically disaffected, working-class vote (Perrineau 2017b) at the risk of further compromising its historic support bases on the more economically liberal, culturally conservative right? Should it continue to implement piecemeal policy revisions or undertake a thorough programmatic review to move at last beyond the FN of Jean-Marie Le Pen? Should it privilege a sovereignist (anti-EU) line over an identitarian (anti-immigration) line or vice versa? Should it change its organisational structures, its campaigning methods, its approach to alliances, its name, or its leader? In a party long used to topdown management, these questions pose potential new opportunities but also potential new threats.

Not for the first time in its history, the FN finds itself at a turning point. The overriding strategic question it confronts is whether, and to what degree, to choose institutional adaptation over anti-system differentiation. Key to its future direction will be the question of whether it defines itself, within classic rational choice categories, as a voteseeking, an office-seeking or a policy-seeking party (Strøm 1990). In other words, is the FN's purpose to weigh in the political balance through maximising popular support even as a force of perennial opposition? Is it to attain elective office - local, regional 
or national - and subordinate its ideological distinctiveness to the pragmatic end of governing? Or is it to amplify its effect on public policy through imposing its priorities on the national political agenda, either within or outside governing coalitions (Müller and Strøm 1999)?

These are not new questions but they are posed with increased urgency for a party that has long evaded them in favour of an ill-defined and opportunistic catch-all strategy. The elections of 2017 showed the limits of that strategy. They also showed the limits of the outsider status that has resulted from the FN's longstanding posture of 'structural opposition’ (Dahl 1966) within the French party system. As it draws the lessons of these elections, the FN must define anew its primary goal - votes, office or policy advocacy - and set a course for achieving that in a more systematic way than hitherto (Harmel and Janda 1994).

So did the elections of 2017 mark a downturn in the FN's fortunes or a further stage in the party's continued rise? The answer, like the election results, must be mixed. These elections saw Marine Le Pen raise the bar for the FN in presidential voting, attracting over a fifth then over a third of votes cast; they witnessed the first ever formal agreement between the FN and another party; they showed a new capacity to generate significant support between the two electoral rounds, both in Le Pen's 3 million additional votes in the presidential run-off and in the parliamentary contests resulting in victory for FN candidates; and they confirmed the weakening of the 'Republican front' as a response to the FN's presence in run-offs. But these elections also showed once again the limits to public support for FN policies and the low levels of confidence in Le Pen’s and her party’s ability to govern (IFOP 2017; Kantar Sofres 2017b). 
Most crucially, however, the elections of 2017 made no meaningful change to the FN's institutional standing. After 45 years of contesting elections at all levels, it holds $0.3 \%$ of municipal council seats, $1.5 \%$ of departmental council seats, $20 \%$ of regional council seats (aided here by the voting system), $0.6 \%$ of Senate seats and, now, $1.4 \%$ of seats in the National Assembly. Between these meagre statistics and being the 'first party of France' there remains, for now, an unbridgeable chasm.

\section{Acknowledgements}

The author wishes to thank the Leverhulme Trust for a Reseach Fellowship that helped him to complete the writing of this article.

\section{References}

Akkerman, T., de Lange S. and Rooduijn, M. (eds) (2016) Radical Right-Wing Populist Parties in Western Europe: Into the Mainstream? Abingdon, Routledge.

Barbier, C. (2015) 'Régionales: une paire de gifles’, L’Express.fr, 8 December.

Baruch, J. (2017) 'Présidentielle: la carte des résultats du second tour, commune par commune’, Le Monde.fr, 8 May 2017.

Beauzamy, B. (2013) 'Explaining the Rise of the Front National to Electoral Prominence: Multi-faceted or Contradictory Models?' In: Wodak, R., KhosraviNik, M. and Mral, B. (eds) Right-Wing Populism in Europe: Politics and Discourse, London, Bloomsbury, pp 177-190.

Benveniste, A. (2016) 'Far-Right Movements in France: The Principal Role of Front National and the Rise of Islamophobia' In: Lazaridis, G., Campani, G. and Benveniste, A. (eds) The Rise of the Far Right in Europe: Populist Shifts and 'Othering', London, Palgrave Macmillan, pp 55-79. 
Camus, J-Y. and Lebourg, N. (2017) Far-Right Politics in Europe, Cambridge MA, the Belknap Press of Harvard University Press.

Courtois, G. (2017) 'Le FN et Marine Le Pen sont entrés dans l'ère du soupçon', Le Monde.fr, 12 September.

Dahl, R. (ed) (1966) Political Opposition in Western Democracies, New Haven, CT, Yale University Press.

Data.gouv.fr (2002) Election présidentielle 2002 - Résultats, accessed at https://www.data.gouv.fr/fr/datasets/election-presidentielle-2002-resultats-572114/ on 8 August 2017.

Data.gouv.fr (2017a) Election présidentielle des 23 avril et 7 mai 2017 - Résultats du 1er tour, accessed at https://www.data.gouv.fr/fr/datasets/election-presidentielle-des23-avril-et-7-mai-2017-resultats-du-1er-tour/ on 8 August 2017.

Data.gouv.fr (2017b) Election présidentielle des 23 avril et 7 mai 2017 - Résultats du 2ème tour, accessed at https://www.data.gouv.fr/fr/datasets/election-presidentielledes-23-avril-et-7-mai-2017-resultats-du-2eme-tour-1// on 8 August 2017.

De Lange (2012) 'New Alliances: Why Mainstream Parties Govern with Radical Right-Wing Populist Parties’, Political Studies, 60 (4), 899-918.

Delwit, P. (2012) 'Le Front national et les élections' In: Delwit, P. (ed) Le Front national. Mutations de l'extrême droite française. Brussels, Editions de l'Université de Bruxelles, pp. 113-142.

Ducourtieux, C. (2017) 'Sur l'euro, Macron relève les ambiguïtés de Le Pen’, Le Monde.fr, 4 May.

Eatwell, R. (2005) 'Charisma and the Revival of the European Extreme Right' In: Rydgren, J. (ed) Movements of Exclusion: Radical Right-Wing Populism in the Western World, New York, Nova Science, pp 101-120.

Ehrhard, T. (2015) 'Le Front National face aux modes de scrutin: entre victoire sous conditions et influences sur le système partisan’, Pouvoirs, 157, 85-103.

Evans, J. and Ivaldi, G. (2017) 'An atypical "honeymoon” election? Contextual and strategic opportunities in the 2017 French legislative elections' French Politics, 15 (3), 322-339.

Faye, O. (2017) 'Florian Philippot cristallise les débats sur la refondation du FN', Le Monde.fr, 21 July.

Faye, O. and Soullier, L. (2017) 'Le jour où le couple Marine Le Pen-Florian Philippot a éclaté’, Le Monde.fr, 21 September.

France Politique (2017a) 'Elections présidentielles', accessed at http://www.francepolitique.fr/elections-presidentielles.htm on 8 August 2017. 
France Politique (2017b) 'Élections législatives', accessed at http://www.francepolitique.fr/elections-legislatives.htm on 8 August 2017.

Front National (2001) Pour un avenir français. Le Programme de gouvernement du Front National, Paris, Editions Godefroy de Bouillon.

Hale Williams, M. (ed) (2009) 'Catch-All in the Twenty-First Century?', Party Politics special issue, 15 (5), special issue, 539-653.

Harmel, R. and Janda, K. (1994) 'An Integrated Theory of Party Goals and Party Change’, Journal of Theoretical Politics, 6 (3), 259-287.

IFOP (2012) Premier tour de l'élection présidentielle 2012: profil des électeurs et clés du scrutin, 22 April.

IFOP (2017) Le profil des électeurs et les clefs du premier tour de l'élection présidentielle 23 avril 2017, 23 April.

IPSOS (2017a) Election présidentielle 2017. 1er tour. Sociologie des électorats et profils des abstentionnistes, 19-22 April.

IPSOS (2017b) Election présidentielle 2017. 2nd tour. Comprendre le vote des Français, 4-6 May.

IPSOS (2017c) Election présidentielle 2017. 2nd tour. Sociologie des électorats et profils des abstentionnistes, 4-6 May.

IPSOS (2017d) Election présidentielle 2017. Intention de vote $2^{\text {nd }}$ tour, 5 May.

IPSOS (2017e) Elections législatives 2017. 1er tour des élections législatives: sociologie des électorats et profil des abstentionnistes, 7-10 June.

Ivaldi, G. (2017) 'L’économie populiste 'attrape-tout' de Marine Le Pen', Le Monde.fr, 16 February.

Jaffré, J. (2017) Le Front National face à l'obstacle du second tour, Paris, Fondation pour l'innovation politique.

Jeune Nation (2014) 'L'homme qui vomissait sur le drapeau français, l'immonde Juif Jean Zay, entrera au Panthéon’, 19 February, accessed at http://www.jeunenation.com/actualite/actu-france/lhomme-qui-vomissait-sur-le-drapeau-francaislimmonde-juif-jean-zay-entrera-au-pantheon.html on 8 August 2017.

Judis, J.B. (2016) The Populist Explosion: How the Great Recession Transformed American and European Politics, New York, Columbia Global Reports.

Kantar Sofres (2017a) Intentions de vote des Français à l'élection présidentielle de 2017, 2-4 March. 
Kantar Sofres (2017b) Baromètre d'image du Front national, March.

Kirchheimer, O. (1966) 'The Transformation of Western European Party Systems' In: La Palombara, J. and Weiner, M. (eds), Political Parties and Political Development, New Jersey, Princeton University Press, pp. 177-200.

Krouwel, A. (2003) 'Otto Kirchheimer and the Catch-All Party', West European Politics, 26 (2), 23-40.

Le Monde (2012) Supplement 'Présidentielle: Résultats premier tour’, 24 April.

Le Monde (2017a) 'Marine Le Pen, une victoire et des doutes', 25 April.

Le Monde (2017b) Supplement 'Résultats: Présidentielle 2017 - premier tour', 25 April.

Le Monde (2017c) Supplement ‘Résultats: Présidentielle 2017 - second tour’, 9 May.

Le Monde (2017d) Supplement 'Résultats: Législatives 2017 - premier tour’, 13 June.

Le Monde (2017e) Supplement 'Résultats: Législatives 2017 - second tour’, 20 June.

Le Monde.fr (2017, 29 April). Que contient l'“accord de gouvernement” entre Marine Le Pen et Nicolas Dupont-Aignan?

Le Parisien.fr (2017) 'Carte. Présidentielle: une commune sur deux a placé Le Pen en tête', 24 April.

Le Pen, M. (2012) 'Mon projet pour la France et les Français’, Paris, Front National.

Le Pen, M. (2017) 144 engagements présidentiels. Marine 2017, Paris, Front National.

Les Echos.fr (2017) 'Sondage quotidien: Marine Le Pen au plus haut, en cette fin de semaine’, 17 March.

Libération.fr (2017) 'Au premier tour, Macron est arrivé en tête dans 240 circonscriptions sur 577’, Sur le live Présidentielle, 28 April.

Mayer, N. (2013) 'From Jean-Marie to Marine Le Pen: Electoral Change on the Far Right’ Parliamentary Affairs, 66 (1), 160-178.

Mayer, N. (2015) 'Le plafond de verre électoral entamé, mais pas brisé' In: Crépon, S., Dézé A. and Mayer, N. (eds) Les faux-semblants du Front national. Sociologie d'un parti politique, Paris, Presses de Sciences Po.

Mergier, A. and Fourquet, J. (2011) Le point de rupture. Enquête sur les ressorts du vote FN en milieux populaires, Paris, Fondation Jean Jaurès. 
Ministère de l'Intérieur (2017a) 'Présidentielles', accessed at https://www.interieur.gouv.fr/Elections/Les-resultats/Presidentielles on 8 August 2017.

Ministère de l'Intérieur (2017b) 'Législatives', accessed at https://www.interieur.gouv.fr/Elections/Les-resultats/Legislatives on 8 August 2017.

Mudde, C. (ed) (2017) The Populist Radical Right: A Reader, Abingdon, Routledge.

Müller, W. and Strøm, K. (eds) (1999) Policy, Office or Votes? How Political Parties in Western Europe Make Hard Decisions, Cambridge, Cambridge University Press.

Opinionway (2017) Premier tour de l'élection présidentielle de 2017.

Sociologie du vote, 23 avril 2017.

Opinionway Présitrack (2017) Synthèse de la semaine du 13 au 17 mars 2017, 17 March.

Perrineau, P. (2014) La France au Front. Essai sur l'avenir du Front national. Paris, Fayard.

Perrineau, P. (2015) 'Montée en puissance et recompositions de l'électorat frontiste', Pouvoirs, 157, 63-73.

Perrineau, P. (2017a) 'Présidentielle: Marine Le Pen bien installée en pole position', Le Figaro, 8 March 2017.

Perrineau (2017b) Cette France de gauche qui vote FN. Paris, Seuil.

Reynié, D. (2011) Populismes: la pente fatale, Paris, Plon.

Shields, J. (2007) The Extreme Right in France: From Pétain to Le Pen, Abingdon, Routledge.

Strøm, K. (1990) 'A Behavioral Theory of Competitive Political Parties', American Journal of Political Science, 34 (2), 565-598. 